\title{
Positive Influence of Guided Inquiry Model Integrated with Tri Hita Karana on Learning Motivation and Critical Thinking Skills
}

\author{
Ni Komang Eka Krisnayanti' ${ }^{1, *}$ I Gede Astawan², Ndara Tanggu Renda ${ }^{3}$ \\ ${ }^{123}$ Elementary School Teacher Education Study Program, Ganesha Educational University, Jl. Udayana No. 11 Singaraja, \\ Bali, Indonesia \\ *Corresponding author: ekakrisnayanti246@gmail.com
}

\begin{abstract}
This study aims to determine the effect of brain based learning models assisted by crossword puzzles on the understanding of concepts and critical thinking skills in science. This research is a quasi-experimental study (quasi-experimental), with a non-equivalent post-test only control group design. The population of this study was the entire class V of SDN Cluster VIII Buleleng District in the academic year 2019/2020 consisting of 5 classes in five elementary schools with 129 students. Samples were taken with a random sampling technique of 2 classes. Data on understanding concepts and critical thinking skills in science is collected using the test method in the form of an essay test. Data were analyzed with the MANOVA test using SPSS 17 for Windows. The results showed that 1) there was a positive influence on the brain based learning model with the help of crossword puzzles on the understanding of the science concept (F count of 276,585; sig =0,000<0.05); 2) there is a positive influence of the brain based learning learning model assisted by the crossword puzzle media on critical thinking skills in science ( $F$ count is 238,963; sig =0,000 <0.05); 3) there is a positive influence on brain based learning models assisted by the crossword puzzle media on the understanding of concepts and critical thinking skills in science ( $F$ count of 231.064; sig $=0.0001<0.05$ ). The brain based learning model with the help of crossword media can be applied to science learning in elementary schools as an effort to increase students' understanding of concepts and critical thinking skills maximally in science lessons.
\end{abstract}

Keywords: brain-based learning; crossword puzzles; understanding the concepts; critical thinking skills

\section{Introduction}

Guided Inquiry learning model is learning that emphasizes the activity of searching and finding a problem (Yuliyanti, 2016). It can develop students' knowledge because in the learning process students are given the opportunity to look for facts, build concepts and apply scientific attitudes. Science is an important aspect of life, it is related to the demands and challenges in facing the era of the industrial revolution 4.0 or fundamental changes in the industrial field that have entered a new era. It can be done by improving the quality of education. Hendriani, et al., (2013) revealed that education has a very important role in determining the quality of development that is owned by a country. The higher the quality of education owned by a country will result in the higher quality of existing human resources, therefore the opportunity to develop the country in a better direction will also be even greater. In this case education is one of the main instruments of Human Resources Development. In 
other words, the education aim's to build and develop personality, skills and intellectual intelligence (Putri, 2018).

The educational goal have three aspects, namely cognitive, affective and psychomotor aspects. In order to achieve these educational goals, a number of formal education programs are held at various levels. Elementary school level is a serious problem faced by the government. Various efforts have been made by the government to improve the quality of education, including basic education. Some of the efforts made by the government include: 1) provision of facilities and infrastructure, 2) procurement of teaching materials and reference books, 3) improving the quality of elementary school teachers through Teacher Professional Education (PPG), 4) innovative learning and 5) improving the curriculum.

These government efforts have not been able to optimally improve the quality of education. According to Relisa (2016), this is evidenced by UNESCO data (2015) on the ranking of the Human Development Index (Human Development Index), which is the composition of the rankings of educational achievement, health, and income per head which shows that the Indonesian human development index is declining. In 2010 Indonesia was ranked 65th, in 2011 it dropped to 69th place, and in 2012 it was down to 68th rank. This shows that every year the quality of Indonesia's education is declining. In addition, the quality of science education in Indonesia is also still low. According to Nugraha, et al. (2017), based on the results of a Trends in Mathematics and Science Study (TIMSS) survey by The International Association for the Evaluation of Educational Achievement (IEA) in 2015, Indonesia ranked 44th out of 47 countries, with an average rating 397. Indonesian students 'scientific ability is below the average value (500) and in general their students' scientific ability is at the lowest level. Factors that cause the low science education in Indonesia is the lack of applying scientific work and teachers more lectures, so students become bored quickly and cause low science learning outcomes (Astrawan, 2013). therefore, scientific attitude and science process skills have not been trained optimally.

It was also revealed from the results of interviews that have been conducted at SDN Cluster $\mathrm{X}$ in Buleleng District, there were several problems that could be encountered, namely the lack of student learning resources so the learning process was less than optimal. In students there is one book on the bench that causes students to turn to read or read together. In addition, students lack participation and are enthusiastic in participating in science learning. This is due to the lack of learning media that can support the ongoing learning process. The condition of the media related to science learning is largely inappropriate for use, so teachers rarely use the media in the learning process. 
Other than the interview step, observations also showed similar results, the learning process that took place was not student-centered. This is because the learning process did not use innovative learning models and the limitations of the media in the learning process. So students have difficulty in understanding the material presented which results in students being less active and tend to be lazy to express their opinions. In addition, teachers rarely invite students to discuss groups so the lack of interaction between students in the learning process undertaken.

Based on these problems, it is necessary to hold updates in the learning system implemented in the classroom. The learning system should be designed so that the learning process that can take place conducive. For this reason, a teacher must master the models, strategies, approaches, methods and techniques in the learning process so that it can improve the quality of student learning. One learning model that can be chosen by the teacher in the learning process that will be implemented to student (student centered) learning is the guided inquiry learning model. Guided inquiry learning model can provide space for students to learn according to their learning styles and students who have good learning skills will not be hampered by students who are weak in learning. So that science learning becomes fun because students play an active role in learning. This is in line with the findings of Amijaya (2018) which states the advantages of the Guided Inquiry learning model, namely providing space or learning opportunities in accordance with their learning styles and in the learning process emphasizes the development of cognitive, affective and psychomotor aspects in a balanced manner. Therefore, in learning with this guided inquiry model, it can form groups, work on shared tasks, exchange ideas with the group, make observations, submit guesses, collect data, and conclude.

In addition, there are some things that become the main characteristics of the guided inquiry learning model according to Yuliyanti (2016), the learning model emphasizes maximum student activity to search and find, all activities carried out by students are directed to find and find themselves from something in question, so expected to foster an attitude of confidence (self belief), develop intellectual abilities as a mental process.

Guided inquiry learning model is a learning model that maximally involves all students' abilities to search and find systematically, critically, and logically, so students can find their own discoveries with confidence (Gulo in Dwi Masitoh 2017). Agustin (2014) states that with the guided inquiry learning model students have the opportunity to learn how to find facts, concepts and principles through direct experience. So, students not only learn by reading and then memorize material from text books or based on information and lectures 
from the teacher, but also have the opportunity to practice developing students' critical thinking skills and scientific attitudes. In line with that, Iman (2017) revealed that learning with a guided inquiry model can improve students' understanding of the material being studied, because students look for and find information on the material themselves. thus students will be able to think critically in the learning process.

Several studies have found that the guided inquiry model influences learning outcomes. Ashari (2019) in the study concluded that there is a positive relationship between learning motivation and critical thinking skills so that student learning outcomes improve. Falahudin (2016) in his research revealed that increasing students' critical thinking skills so that students are able to solve problems with the process of inquiry in a systematic, logical and critical manner. Research conducted by Dewi (2013) shows that the guided inquiry model can increase scientific attitudes and student learning outcomes. Through this scientific attitude students can interact between other students and the surrounding environment.

This guided inquiry learning model can be optimized by integrating Balinese local wisdom. The application of the guided inquiry model based on Tri Hita Karana is expected to enhance interaction between students who respect each other. Besides the occurrence of student relationships with the environment in accordance with the steps of the guided inquiry learning model in collecting data around the school, students can maintain cleanliness and care for it well. One of the local Balinese wisdoms that is properly integrated in science learning is Tri Hita Karana. According to Pradnyawathi \& Agustika (2019), Tri Hita Karana are the three elements that cause happiness and human well-being that come from harmonious relations between living things. This concept appears related to the existence of community life. In Tri Hita Karana includes a balance relationship between humans and God (parahyangan), a harmonious balance relationship between human beings (pawongan), and finally a harmonious balance relationship between humans and nature (palemahan).

If the guided inquiry learning model is integrated with Tri Hita Karana, it will be better and can create active and fun learning. This is the basis for teaching humans to be able to seek a harmonious relationship with God, with fellow human beings, and with the natural environment. According to Astami (2016) the guided inquiry learning model based on Tri Hita Karana is a combination of learning models that direct students to conduct investigations in overcoming problems and coupled with the practice of Tri Hita Karana's local wisdom values so that they can form a better social attitude. In addition, if learning is integrated with Tri Hita Karana it can motivate and train students' critical thinking skills. Students' thinking skills are very important to be developed so that students are able to solve a problem and 
make decisions that are appropriate and in accordance with scientific truth. This research aims to determine whether there is a significant influence of the guided inquiry learning model based on Tri Hita Karana on students' motivation and critical thinking skills in science.

\section{MATERIALS AND METHODS}

This research uses a quantitative research design with the type of research is quasi experiment, because not all variables (symptoms that arise) and conditions can be tightly controlled and controlled. The research design used in this study is non equivalent posttest only control group design. procedurally follow as in Table 1.

Table 1. Rancangan Penelitian

\begin{tabular}{lccc} 
& Class & Treatment & Post-test \\
\hline Experiment & $\mathrm{X}$ & $\mathrm{O}_{1}$ \\
\hline Control & - & $\mathrm{O}_{2}$ \\
\hline
\end{tabular}

(modified by Sugiyono, 2017)

Information:

$\mathrm{O} 1=$ post-test of the experimental class

$\mathrm{O} 2=$ post-test of the control class

$\mathrm{X}=$ treatment of the experimental class (guided inquiry learning model based on Tri Hita Karana)

- = no treatment was given to the control class (not given a guided inquiry learning model based on Tri Hita Karana)

The population of this study was all class IV (four) Elementary School Cluster X Buleleng district in the academic year 2019/2020. Consists of 5 classes in 5 elementary schools. With a population of 126 people in the study. The sample selection used as the experimental class and the control class was done by cluster random sampling. Cluster random sampling is used because individual randomization is not done but only randomization of classes, because it can not change classes that have been formed previously. Classes are selected as formed without the intervention of the researcher and randomization of the individual is not done. So that each class gets the same opportunity to become a research sample. All classes are drawn to determine the experimental class and the control class. Based on the draw, the experimental class and the control class in Buleleng $\mathrm{X}$ Elementary School in Buleleng District were obtained, all grade IV students at SDN 1 Kaliuntu as the experimental group and all class IV in SDN 3 Kaliuntu as the control group.

There are two data in this study, namely motivation to learn and critical thinking skills in science. Data on student motivation was collected by non-test in the form of a learning motivation questionnaire whose assessment was using the Likert scale. Indicators of 
learning motivation examined in this study are students 'perseverance in learning, being tenacious in facing difficulties, interests and sharpness of students' attention in learning, achievement in learning and independent in learning. Learning motivation can be seen from the scores obtained by students by filling in the questionnaire given the maximum score for each question is 5 , and the minimum score for each question is 1 . This questionnaire contains 30 statements that must be answered by students. Learning motivation tests are theoretically and empirically tested. Theoretically, the learning motivation is tested through expert testing, while empirically, it is carried out with a validity and reliability test. Based on theoretical and empirical tests, out of 30 items, 20 were declared suitable for post-test.

While the data on critical thinking skills are collected by testing critical thinking skills in the form of essay questions. Indicators of critical thinking skills examined in this study are providing simple explanations, providing arguments, making decisions and implementing, determining the source of information, and conducting evaluations. Critical thinking skills can be seen from the scores obtained by students by answering the essay questions given with a maximum score for each question is 5 , and the minimum score for each question is 0 . The essay test contains 10 questions that must be answered by students. Critical thinking skills tests are tested theoretically and empirically. Theoretically, the critical thinking skills are tested through expert tests, while empirically, they are carried out with validity tests, reliability tests, difficulty levels tests and distinguishing power tests. Based on theoretical and empirical tests, out of 10 items, 6 were declared suitable for post-test

Next, the data were analyzed descriptively and inferentially. Before an inferential test is performed, the data distribution normality requirements test, the variance homogeneity test, and the correlation between bound variables are carried out. Testing the normality of data distribution using the Kolmogrov Test and Shapiro-Wilks Test. Criteria for testing data has a distribution of normal distribution if the resulting significance number is greater than 0.05. The normality test can be carried out with the help of the SPSS 17 for Wiindows program. Homogeneity test of variance between groups using the Leven's test of Equality of Error Variance. Criteria for testing data have the same variance (homogeneous) if the significance number obtained is greater than 0.05 in other words if the sample variance is not the same (not homogeneous). Homogeneity variance test can be done with the help of SPSS 17 for Wiindows program. Testing the correlation between dependent variables using Pearson (Pearson's product moment). The data testing criteria are said to be not correlated if the significance value of the analysis results shows more than 0.05 . Test correlation between dependent variables using the help of SPSS 17 for Wiindows. 


\section{Results and Discussion}

The results of the hypothesis test in this study prove that: First, there is an influence of the Tri Hita Karana Guided Inquiry learning model on the motivation to learn science. The results of calculation of hypothesis 1 using SPSS 17.0 for windows can be seen in Table 2 .

Table 2. Hypothesis Testing

\begin{tabular}{|c|c|c|c|c|c|c|}
\hline & \multicolumn{6}{|c|}{ Tests of Between-Subjects Effects } \\
\hline Source & Dependent Variable & $\begin{array}{l}\text { Type III Sum of } \\
\text { Squares }\end{array}$ & df & Mean Square & $\mathrm{F}$ & Sig. \\
\hline \multirow[t]{2}{*}{$\begin{array}{l}\text { Corrected } \\
\text { Model }\end{array}$} & $\begin{array}{l}\text { Motivasi_Belajar_ } \\
\text { Eksperimen }\end{array}$ & $1437.415^{\mathrm{a}}$ & 1 & 1437.415 & 161.679 & 0.000 \\
\hline & $\begin{array}{l}\text { Berpikir_Kritis_ } \\
\text { Eksperimen }\end{array}$ & $563.575^{\mathrm{b}}$ & 1 & 563.575 & 85.728 & 0.000 \\
\hline \multirow[t]{2}{*}{ Intercept } & $\begin{array}{l}\text { Motivasi_Belajar_Ekspe } \\
\text { rimen }\end{array}$ & 336688.479 & 1 & 336688.479 & 37870.441 & 0.000 \\
\hline & $\begin{array}{l}\text { Berpikir_Kritis_ } \\
\text { Eksperimen }\end{array}$ & 24740.085 & 1 & 24740.085 & 3763.328 & 0.000 \\
\hline \multirow[t]{2}{*}{ Class } & $\begin{array}{l}\text { Motivasi_Belajar_Ekspe } \\
\text { rimen }\end{array}$ & 1437.415 & 1 & 1437.415 & 161.679 & 0.000 \\
\hline & $\begin{array}{l}\text { Berpikir_Kritis_ } \\
\text { Eksperimen }\end{array}$ & 563.575 & 1 & 563.575 & 85.728 & 0.000 \\
\hline \multirow[t]{2}{*}{ Error } & $\begin{array}{l}\text { Motivasi_Belajar_Ekspe } \\
\text { rimen }\end{array}$ & 400.074 & 45 & 8.891 & & \\
\hline & $\begin{array}{l}\text { Berpikir_Kritis_ } \\
\text { Eksperimen }\end{array}$ & 295.830 & 45 & 6.574 & & \\
\hline \multirow[t]{2}{*}{ Total } & $\begin{array}{l}\text { Motivasi_Belajar_Ekspe } \\
\text { rimen }\end{array}$ & 352898.000 & 47 & & & \\
\hline & $\begin{array}{l}\text { Berpikir_Kritis_ } \\
\text { Eksperimen }\end{array}$ & 27311.000 & 47 & & & \\
\hline \multirow[t]{2}{*}{$\begin{array}{l}\text { Corrected } \\
\text { Total }\end{array}$} & $\begin{array}{l}\text { Motivasi_Belajar_Ekspe } \\
\text { rimen }\end{array}$ & 1837.489 & 46 & & & \\
\hline & $\begin{array}{l}\text { Berpikir_Kritis_ } \\
\text { Eksperimen }\end{array}$ & 859.404 & 46 & & & \\
\hline
\end{tabular}

Based on the results of the analysis with SPSS 17.0 for windows the science learning motivation data which is taught by the Guided Inquiry learning model based on Tri Hita Karana and not taught by the Guided Inquiry model based on Tri Hita Karana produces an F of 161,679 with a significance of 0,000 . If the significance level is set $\alpha=0.05$, it can be concluded that the null hypothesis (H0) is rejected, the alternative hypothesis (H1) is accepted. So there is the influence of the Guided Inquiry learning model based on Tri Hita Karana on the learning motivation of Natural Science class IV SDN Cluster X Bulelen District 2019/2020 school year. 
Second, the results of the analysis show that there is an influence of the Tri Hita Karana-based Guided Inquiry learning model on critical thinking skills. The results of the calculation of hypothesis 2 with SPSS 17.0 for Windows. Was obtained

the results of data analysis of critical thinking skills of science taught by the Guided Inquiry learning model based on Tri Hita Karana and not being taught the Guided Inquiry learning model based on Tri Hita Karana produces an F of 85,728 with a significance of 0,000 . If the significance level is set $\alpha=0.05$, so it can be concluded that the null hypothesis (H0) is rejected, the alternative hypothesis (H1) is accepted. This means that there is an influence of the Tri Hita Karana-based Guided Inquiry learning model on the critical thinking skills of Class IV Natural Sciences SDN Cluster $\mathrm{X}$ in Bulelen District in the academic year 2019/2020.

Third, the results of the analysis show that there is an influence of the Tri Hita Karana based Guided Inquiry learning model on learning motivation and critical thinking skills in Natural Sciences. The results of calculation of hypothesis 3 using MANOVA (Multivariate Analysis of Variance) assisted by SPSS 17.0 for windows can be seen in Table 3.

Table 3. Multivariate Tests

\begin{tabular}{llrrrrr}
\hline Effect & & Value & \multicolumn{1}{c}{ F } & Hypothesis df & Error df & Sig. \\
\hline Intercept & Pillai's Trace & 0.999 & $19521.708^{\mathrm{a}}$ & 2.000 & 44.000 & 0.000 \\
& Wilks' Lambda & 0.001 & $19521.708^{\mathrm{a}}$ & 2.000 & 44.000 & 0.000 \\
& Hotelling's Trace & 887.350 & $19521.708^{\mathrm{a}}$ & 2.000 & 44.000 & 0.000 \\
& Roy's Largest Root & 887.350 & $19521.708^{\mathrm{a}}$ & 2.000 & 44.000 & 0.000 \\
\hline Kelas & Pillai's Trace & 0.836 & $112.193^{\mathrm{a}}$ & 2.000 & 44.000 & 0.000 \\
& Wilks' Lambda & 0.164 & $112.193^{\mathrm{a}}$ & 2.000 & 44.000 & 0.000 \\
& Hotelling's Trace & 5.100 & $112.193^{\mathrm{a}}$ & 2.000 & 44.000 & 0.000 \\
& Roy's Largest Root & 5.100 & $112.193^{\mathrm{a}}$ & 2.000 & 44.000 & 0.000 \\
\hline
\end{tabular}

Descriptive research results describe the results of the calculation of the mean, standard deviation, range, score / maximum value, score / value, minimum. Based on the descriptive analysis conducted there are four scores indicating that descriptively the group of students who were taught using the Guided Inquiry learning model based on Tri Hita Karana was higher than the group of students who were not taught the Guided Inquiry learning model based on Tri Hita Karana.

From the results of the analysis conducted on the first hypothesis test in this study, the coefficient $F$ value was 161,679 with a significance of 0,000 . If the significance level is set $\alpha=0.05$, the first hypothesis is accepted, meaning that there is an influence of the Tri Hita 
Karan Guided Inquiry learning model on student motivation. Based on the second hypothesis test in this study, the coefficient $F$ value was 85,728 with a significance of 0,000 . If the significance level is determined $\alpha=0.055$, the second hypothesis is accepted, meaning that there is an influence of the Tri Hita Karana-based Guided Inquiry learning model on students' critical thinking skills. Based on the results of the third hypothesis test in this study, the value of F Pillai's Trace, Wilks' Lambda, Hotelling Trace, Roy's Largest Root was 112,193 all of which had a significance of 0,000 and were smaller than $0.005(0,000<0.05)$. This shows that there is a positive influence of the Tri Hita Karana-based Guided Inquiry learning model on students' learning motivation and critical thinking skills as evidenced by the average value of students above KKM. In addition, with the Guided Inquiry model based on Tri Hita Karana students are able to solve the problems given with confidence and students can express their ideas so that students exchange ideas with their friends. Therefore, students are active in the learning process.

The results of this study prove that the Guided Inquiry model based on Tri Hita Karana has a positive effect on students' motivation and critical thinking skills in science. In implementing learning in the classroom the teacher must have the ability to manage the class well so as to create a pleasant and conducive atmosphere so that students are able to easily understand the learning material. The teacher gives the problem to students, then students are directed to formulate the problem from the problem, after the problem formulation there is then the student makes a temporary answer from the formulation of the problem proposed. In solving problems students need resources to help solve existing problems. In solving problems given by students conducting experiments, after conducting experiments students make conclusions from the results of experiments that have been done. Unlike the case with learning with conventional approaches where the learning process is dominated by the teacher. So that such learning does not provide experience to students and students will quickly feel bored because of the low interest of students to learn.

Based on this, learning by using the Guided Inquiry learning model provides an opportunity for students to play an active role besides the teacher providing guidance to students, so students who think slowly are able to follow the activities being carried out. According Suryaningsih, et al., (2016) Inquiry learning is a learning activity that maximally involves all students' abilities to search for and investigate something (objects, people or events) systematically in observing images, critically in giving questions, analytically so that they can formulate themselves his discovery with confidence. The Guided Inquiry learning model based on Tri Hita Karana can arouse student motivation. Motivation is an important 
factor in improving learning achievement. High motivation in learning will result in good learning outcomes (Sunadi 2013). So the ability to think critically is related to the motivation of learning possessed by someone. Motivation to learn is the overall driving force within students that gives rise to learning activities, which ensures continuity of learning activities and gives direction to learning activities, so that desired activities are achieved (Nugraha, 2017).

There is a direct correlation between learning motivation and critical thinking skills. It means that the higher the student's motivation to learn, the better the learning outcomes (Pratama, et al.2020). In order for the learning process to be effective it is necessary to involve critical thinking skills, with learning motivation will produce good or even better learning outcomes. According to Harson, et al. (2018) states Critical thinking is a skill gained from the learning process to develop cognitive abilities and store information effectively. Meanwhile, according to Sutama, 2014 students' thinking skills can be done by always asking and questioning various phenomena that are being studied. Therefore using Tri Hita Karanabased Guided Inquiry provides an opportunity for students to develop critical thinking skills so that students are able to solve problems found in the learning process. The Guided Inquiry learning model provides opportunities for students to question, search for information and knowledge. Knowledge obtained is not the result of remembering words but able to understand, find themselves, because by finding themselves students can understand more deeply (Furmanti, 2019).

In addition, the strengths of the Guided Inquiry learning model that is to provide space or learning opportunities in accordance with their learning styles and in the learning process emphasizes the development of cognitive, affective and psychomotor aspects in a balanced manner. (Amijaya, 2018). So that in the learning process students are able to build their knowledge with active and fun learning. One example of active students in the learning process is students always ask questions when discussing. Referring to the above, a success obtained from students is determined by how able students build their knowledge and understanding of a learning material based on experiences gained or experienced directly by students.

Ashari Research, (2019) shows that there is an influence of learning motivation and critical thinking skills of students who follow the Guided Inquiry learning model is higher than students who are not taught with the Guided Inquiry learning model. There is a positive relationship between motivation and critical thinking skills in learning science. Students who have low learning motivation also have low critical thinking skills and vice versa. Research 
conducted by Amijaya, et al (2018) states the Guided Inquiry learning model is a learning model that places students as learning subjects, which means that each student is encouraged to be actively involved in learning activities. The Guided Inquiry learning model can improve students 'critical thinking skills, because the Guided Inquiry learning model is able to involve all students' abilities to search for and discover phenomena systematically.

The results of research conducted by Indriyani (2019) found that the average critical thinking skills of students who took part in learning with the Guided Inquiry model based on Tri Hita Karana were better than students who were not taught with the Guided Inquiry model based on Tri Hita Karana. According to Putri, (2018) The guided inquiry learning model is a student-centered learning process that provides opportunities for students to actively participate in finding and utilizing learning resources.

These findings have several implications, namely: (1) to develop the ability to solve problems systematically and express the ideas they have in science learning, a Guided Inquiry learning model based on Tri Hita Karana can be applied as an alternative learning facility. (2) learning motivation is very important in the learning process, because with the motivation to learn can encourage students in the learning process so that students have passion, enthusiasm and a sense of pleasure in learning. (3) relating to learning that exercises critical thinking skills, the application of the Guided Inquiry learning model based on Tri Hita Karanah must pay attention to how to research, unite, make decisions, and create and apply new knowledge to real world situations.

\section{CONCLUSION}

Based on the results of hypothesis testing and discussion, the conclusion of this study is that there is an influence of the Guided Inquiry learning model based on Tri Hita Karana on the learning motivation of Grade IV students of SDN Cluster X in Buleleng District in the academic year 2019/2020, there is the influence of the Tri Hita Karan based Guided Inquiry learning model on skills Critical thinking of Class IV students of Elementary School Cluster X in Buleleng District in 2019/2020, there is an influence of Tri Hita Karan's Guided Inquiry learning model on the motivation to learn and critical thinking skills of Science in Class IV students of Elementary School Cluster X in Buleleng District in 2019/2020.

\section{ACKNOWLEDGMENTS}

The author would like to thank for the guidance, advice and assistance in the form of both moral and material from various parties. For this reason, on this occasion, the authors 
thank; the principal of Kaliuntu 1 Elementary School and Kaliuntu 3 Elementary School have given permission for the authors to conduct research in the school they lead. And Mr. and Mrs. Lecturers in the Department of Basic Education, Ganesha University of Education who have provided assistance and motivation to the writer.

\section{References}

Agustin, Risa, and Imam Supardi. 2014. "Penerapan Model Pembelajaran Inkuiri Terbimbing Untuk Melatihkan Kemampuan Keterampilan Berpikir Kritis Siswa Kelas XI SMAN 1 Kalianget.” Inovasi Pendidikan Fisika 3 (2): 14-19.

Amirjaya, Lalu Sunarya, Agus Ramdani I Wayan Merta. 2018. "Pengaruh Model Pembelajaran Inkuiri Terbimbing Terhadap Hasil Belajar Dan Kemampuan Berpikir Kritis Peserta Didik" 13 (2): 94-99.

Astami, Ni Wira, I Wyn Wiarta, I Wyn Darsana, and Jurusan Pgsd. 2016. "Kompetensi Pengetahuan IPS Universitas Pendidikan Ganesha Tujuan Pendidikan Nasional ( Pasal" 17.

Astrawan, I Gede Budi. 2013. "Penerapan Model Kooperatif Tipe NHT Dalam Meningkatkan Hasil Belajar Siswa Pada Mata Pelajaran IPA Di Kelas V SDN 3 Tonggolobibi." Jurnal Kreatif Tadulako Online 3 (4): 227-42.

Dewi, Narni Lestari. Nyoman Dantes. 2013. "Pengaruh Model Pembelajaran Inkuiri Terbimbing Terhadap Sikap Ilmiah Dan Hasil Belajar IPA" 3 (2).

Falahudin, Ilham, Indah Wigati, Ayu Pujiastuti. 2016. "Pengaruh Model Pembelajaran Inkuiri Terbimbing Pembelajaran Materi Pengelolaan Lingkungan” 2 (2): 92-101.

Furmanti, Tessy, Rusdi Hasan, Pascasarjana Universitas, and Muhammadiyah Bengkulu. n.d. "Pengaruh Model Pembelajaran Inkuiri Terbimbing Terhadap Kemampuan Berpikir Kritis , Motivasi Dan Keaktifan Siswa Di SMP N 5 Seluma,” 1-9.

Herzon, Hayuna Hamdalia, Budijanto, and Dwiyono Hari Utomo. 2018. "Pengaruh ProblemBased Learning (PBL) Terhadap Keterampilan Berpikir Kritis." Jurnal Pendidikan Teori, Penelitian, Dan Pengembangan $3 \quad$ (1): 42-46. http://journal.um.ac.id/index.php/jptpp/.

Iman, Rasulun, Ibnu Khaldun, Nasrullah. 2017. "Meningkatkan Kemampuan Berpikir Kritis Siswa Dengan Model Inkuiri Terbimbing Pada Materi Pesawat Sederhana" 05 (01): 5258.

Indriyani, Dina, Mawardi, Krisma Widi Wardani. 2019. "Peningkatan Keterampilan Berpikir Kritis Melalui Model Inkuiri Berbantuan Media Konkret Pada Siswa Kelas 5 SD Negeri Mangunsari 05 Tahun Pelajaran 2018/2019” 3 (1): 27-32.

Made, Ni, Ayu Suryaningsih, I Made Elia Cahaya, Christiani Endah Poerwati, Studi Pendidikan, Guru-pendidikan Anak Usia, and Universitas Dhyana Pura. 2016. "Implementasi Pembelajaran Inkuiri Terbimbing Berbasis Permainan Dalam Meningkatkan Kreativitas Anak Usia Dini Ni” 5 (2).

Masitoh, Ikhlasun Dwi, and Joko Ariyanto. 2017. "Pengaruh Model Pembelajaran Inkuiri Terbimbing Terhadap Kemampuan Berpikir Kritis Siswa Kelas X MIA Pada Materi Pencemaran Lingkungan Di Surakarta The Influence of Guided Inquiry Learning Toward Critical Thinking Skills of X MIA Students on Environtmental Pollution 
Material in Surakarta" 10: 71-79.

Nugraha, Arief Juang, Hardi Suyitno, and Endang Susilaningsih. 2017. "Analisis

Kemampuan Berpikir Kritis Ditinjau Dari Keterampilan Proses Sains Dan Motivasi Belajar Melalui Model PBL Abstrak" 6 (1): 35-43.

Nym, Ni, Chintya Pradnyawathi, Gst Ngr, and Sastra Agustika. 2019. "Pengaruh Model Pakem Berbasis Tri Hita Karana Terhadap Keterampilan Menulis" 3 (1): 89-98.

Pratama, P. Y. S., Utami, I. G. A. L. P., \& Adnyani, L. D. S. (2020). An Analysis of English Language Education (ELE) Students' Motivation in Learning Pedagogical Courses. Jurnal Pendidikan Indonesia, 9(1), 131-141. https://ejournal.undiksha.ac.id/index.php/JPI/article/view/23516

Pt, Luh Vony Hendriani, Gd, Raga, Dw, Kade Sastra. 2013. "Pengaruh Model Pembelajaran Kontekstual Berbasis Tri Hita Karana Terhadap Hasil Belajar PKN di SD."

Pt, Ni, Linda Kusuma, Nyoman Kusmariyatni, and I Nyoman Murda. 2018. "Pengaruh Model Pembelajaran Inkuiri Terbimbing Berbantuan Media Audio-Visual Terhadap Hasil Belajar IPA," 153-60.

Relisa. 2016. "Kajian Prasarana Pendidikan Sekolah Dasar Sebagai Salah Satu Indikator Pencapaian Standar Nasional Pendidikan Study Of Primary School Infrastructure As One Of Indicator In" 1 (19): 81-96.

Sugiyono. 2017. Metode Penelitian Kuantitatif, Kualitatif Dan R \& D. Alfabeta, Bandung.

Sunadi, Lukman. n.d. "Pengaruh Motivasi Belajar Dan Pemanfaatan Fasilitas Belajar Terhadap Prestasi Belajar Siswa Pada Mata Pelajaran Ekonomi Kelas Xi IPS di SMA Muhammadiyah 2 Surabaya," 1-19.

Sutama, I Nyoman, Ida Bagus, Putu Arnyana, Ida Bagus, and Jelantik Swasta. 2014. "Pengaruh Model Pembelajaran Inkuiri Terhadap Pada Pelajaran Biologi Kelas Xi IPA SMA Negeri 2 Amlapura Singaraja Indonesia” 4.

Yulianti, Novi. 2016. "Pengaruh Model Inkuiri Terbimbing Berbasis Lingkungan Terhadap Kemampuan Pemahaman Konsep Dan Karakter” 2 (2). 